\title{
"We Consider Him as a Menace to Our Family": Extended Family Variances in Attitudes Towards People with Schizophrenia
}

\author{
Ni Luh Kade Nadia Rastafary ${ }^{1, *}$, Marselius Sampe Tondok ${ }^{2}$
}

\author{
${ }^{1,2}$ Universitas Surabaya \\ *Corresponding authr e-mail: nadiarastafary96@gmail.com
}

\begin{abstract}
Schizophrenia is a psychotic mental disorder that causes psychiatric symptoms, such as confusion in thinking, emotions, perceptions, and deviant behaviour. The prevalence of schizophrenia/ psychosis in Indonesia was 6.7 per 1000 households. The highest prevalence distribution was in Bali and Yogyakarta province, with 11.1 and 10.4 out of 1,000 households having members who suffered from schizophrenia/ psychosis, respectively. A positive attitude from Orang dengan Schizophrenia (ODS) or people with schizophrenia's family are able to reduce the impact of schizophrenia and directly strengthen their mental health. But most people in Indonesia who are having schizophrenia as their family member usually choose to hide, isolate and treat them inhumanely. This study aims to determine extended family variances in attitudes towards people with schizophrenia living together and living in different homes. The method used in this study was a qualitative phenomenological approach. The participants were five people from ODS' extended family living in Bali. This study applied semi-structured interviews and observations in data collection. The data was analysed using theoretical coding. The result showed that the extended family variances in attitudes towards family members with schizophrenia's living together and living in different houses was examined in aspects, 1) perception, 2) feeling and 3) behaviour. In fact, the extended family's attitude towards their family member with schizophrenia who lived in the same home tended to be more positive than those who lived in different homes. The overall result would be discussed later.
\end{abstract}

Keywords: attitude, extended family, schizophrenia.

\section{INTRODUCTION}

Schizophrenia is a psychotic mental disorder that causes psychiatric symptoms, such as confusion in thinking, emotions, perceptions, and deviant behaviour, with the main symptoms being delusions (false beliefs), delusions (wrong views), and hallucinations (perception without sensory stimulation).

According to the data from World Health Organization (WHO) [1], schizophrenia is a serious mental disorder. Currently, the number of people with schizophrenia or in Indonesia, it is called Orang Dengan Schizophrenia (ODS) is increasing. This is due to various kinds of problems they experience, ranging from worsening economic conditions, poor family conditions or parenting to emerging natural disasters. WHO also stated that in 2013 the number of schizophrenics reached 450 million worldwide.

Basic Health Research or Riset Kesehatan Dasar (Riskesdas) 2018 shows that the prevalence of schizophrenia / psychosis in Indonesia is 6.7 per 1,000 households [2]. This means that out of 1,000 households, there were 6.7 households that had members with schizophrenia / psychosis. The highest prevalence distribution was in Bali, with 11.1 out of 1,000 households, each had a member suffering from schizophrenia / psychosis.

In general, the results of the 2018 Riskesdas study also describes that $84.9 \%$ of schizophrenia / psychosis sufferers in Indonesia had received 
treatment. However, there are fewer people who took drugs regularly than those who did not. It is recorded that $48.9 \%$ of psychosis sufferers do not regularly take medication and $51.1 \%$ regularly consumed it. As many as $36.1 \%$ of sufferers who do not regularly take medication in the past month admit feeling healthy. As many as $33.7 \%$ of patients do not seek treatment regularly and $23.6 \%$ cannot afford to buy medicine regularly. Another problem where people with schizophrenia / psychosis is that they are shackled by their families. The proportion of households who have chained schizophrenia / psychosis members reaches $14 \%$.

Families are thought to know best about the condition of ODS and are considered to be the most influential factor on ODS. This shows that the role of family is very important in the treatment and healing phase of ODS. The main important reasons for family's role in mental care are: (1) Family is a unit most associated with the attitude of ODS towards pasung (case study at RSJ Amino Gondohutomo Semarang), (2) Mental disorders emerging in ODS may be caused by parenting, (3) ODS will later return to the community preceded by a family environment, (4) Family is the main care in achieving basic needs fulfilment and optimising mental peace for ODS, (5) Mental disorders may require a long therapy, so family support and cooperation is very important in the process [3].

A positive attitude and social support from ODS families can reduce the impact of mental disorders experienced and directly strengthen the mental health of ODS [4]. A positive attitude from the family is an important coping strategy for ODS. It also can be a preventive strategy to reduce distress and its negative consequences. It benefits mental development and a healthy personality without distraction. Consequently, it can be said that a positive family attitude is very useful for preventing and reducing distress in ODS, improving emotional health in ODS and helping improve mental health of ODS.

\subsection{Attitude}

According to Myers [5], attitude is a favourable or unfavourable evaluative reaction toward something or someone, exhibited in one's belief, feelings or intended behaviour. Attitude has 3 components: 1) Cognitive Components: consist of belief, knowledge and facts about the object of attitude; 2) Affective component: mood, emotions and activity of the sympathetic nervous system experienced by the individual in relation to the object of attitude; 3) Conative Component: a tendency to act towards the object of attitude [5].

Attitude can be positive and can also be negative. A positive attitude tends to get close to ODS, like, expecting certain objects. A negative attitude has a tendency to stay away, avoid, hate, dislike certain objects [6]. Attitude measurement can be done either directly or indirectly. Directly asks how the respondents' opinions or statements on an object. Indirectly can be done with hypothetical questions and then ask the respondents' opinions through a questionnaire [7].

\subsection{Extended Family}

According to Sudiharto [8], extended family is a family outside the nuclear family, for example grandparents, uncles, aunts, sons-in-law, in-laws, cousins. Bailon and Maglaya [9] state that the extended family is a family consisting of three generations, such as uncle, grandfather, grandmother, nephew. Extended families can live in the same house or in different houses, and may come from different areas.

\subsection{Research Question}

The question that would be answered through this research was the difference in the attitudes of the extended family towards ODS who live in the same house and different house. The study focused on the subjective experiences and interpretations of a phenomenon encountered by individuals. The research was conducted by understanding the participants' daily life experiences with ODS in cognitive, affective and conative aspects.

\section{METHOD}

\subsection{Research Design}

This study used a qualitative method to investigate things contained in the natural environment and try to interpret these phenomena. Qualitative research is defined as planned activities, including a set of interpretive practices that make the world of participants and informants visible. There are five methodological approaches in qualitative research, namely: biography, phenomenology, grounded theory, case studies, and ethnography. The 
research perspective used is in accordance with the objectives of this study, namely; phenomenology which examines the differences in attitudes of extended families towards ODS who live at home and do not live at home [10][11].

\subsection{Data Source}

Sources of the data in this study were individuals who were often referred to as participants, collected by purposive sampling technique with several criteria, namely (1) having additional families (grandparents, in-laws, in-laws, uncles, aunts and cousins) who have or are currently experiencing schizophrenia; (2) aged 18-40 years; (3) originating and domiciled in Bali. There were five participants in the research interviewed eight times in the period from 09 October to 4 December 2016 in Denpasar City and Gianyar Regency.

\subsection{Data Collection Method}

\subsubsection{Interview}

Interview is a data collecting technique by conducting direct dialogues with data sources, which is carried out in a structured manner according to the designed guidelines. The questions raised include; (1) What do you think about the disorders experienced by ODS? (2) How did you feel when you met ODS? (3) What did you do when you met ODS? etc. Open-ended questions were asked to participants to provide detailed answers to what they wanted to say. Open-ended questions will facilitate the dialogue process and help participants describe their experiences clearly without any engineering elements [11][12].

\subsection{Credibility}

In this study, there were several codes of ethics that must be considered. Researchers must be able to hold back emotions towards participants when participants have thoughts, habits that are different from most people. Researchers should not give striking reactions that are unpleasant to participants [13]. In addition, the confidentiality of participants' personal data is also protected by providing informed consent and using initials in writing reports.

\section{RESULT}

This research produced a big theme, namely the differences in the attitude of the extended family of ODS living in the same house and separate house. The results of the study would be discussed separately for each participant.

\section{PSP}

PSP is a 53-year-old woman, who worked as a clothing trader in Gianyar Market, where high school was her last education. PSP's sister-in-law was an ODS who did not live with her. From a cognitive perspective, PSP viewed that mental disorders experienced by ODS were a result of unresolved prolonged stress that manifested by seeking other people's attention, such as shouting and laughing at themselves. PSP felt sorry for the condition of ODS, but still considered the condition of ODS disturbing the extended family's reputation and peaceful life. When meeting with ODS, PSP usually did not greet or initiate a conversation for fear of provoking ODS's anger. PSP also avoided looking at ODS for fear of being attacked.

\section{IN}

IN was a 19-year-old woman. IN was a medical student. IN's male cousin was an ODS who does not live with her According to IN, the ODS cousin experienced hallucinations and needed to be assisted with drugs in order to reduce hallucinations so that his behavior was not aggressive. IN admitted that she felt sorry for the condition of ODS, especially his family who also had to deal with negative symptoms of ODS such as tantrums. When meeting with ODS, IN tended to avoid and stay away, so as not to see ODS's behaviour and prefer the medical principle of securing themselves first.

\section{$J M K$}

JMK was a 24-year-old woman. JMK was a private employee with the latest education on computer systems. JMK's aunt was an ODS who did not live in the same house as her. JMK viewed that the disorder experienced by ODS was caused by stress and inability to solve problems, so that they disturbed her brain. JMK also considered this disturbance was caused by ODS' religious convertion to get married with her husband, so that it became a kind of curse. JMK was ashamed of 
ODS's situation because it was often discussed by neighbours, relatives and even friends. JMK was also afraid of the symptoms of ODS. JMK was usually indifferent when meeting with ODS, because this was the best option for her so that she did not act quirky when chatting with ODS.

\section{$K \boldsymbol{D}$}

KD was a 32-year-old male. KD was a construction worker whose latest education was junior high school (SMP). His uncle was ODS who lived together in the same house with him, even though it was a different building.

"He was sick, I think he could not be cured, because he had been hospitalized but not healed. It's not his fault, maybe the strength of people's minds is different. I feel sorry for him because his daily life is hampered, but I am not ashamed, because it is the same as physical pain. If I meet him, I get him some food and his favorite coffee and cigarettes. I ask him to just sit down even though he doesn't join the chat."

KD considered that the disorder experienced by ODS was an incurable disease, because after being treated for two weeks at the Bangli Mental Hospital, sometimes ODS was still raging at home. KD also added that this disease was similar to memory loss. KD felt sorry but he did not feel ashamed because he thought that mental disorders were the same as physical illnesses. For him, the power of the mind of each person was different, so that some were more susceptible to mental disorders than the others. KD also invited ODS to join in conversations, and sit together even though ODS did not participate in the chat.

\section{$A R D$}

ARD was a 49-year-old male. ARD was a grocery store owner whose latest education was high school (SMA). ODS was ARD's brother-in-law who lived in the same house with him.

"For me it is a disease and can be treated, so he has to be diligent in taking medicine. He is already disturbed by disease, do not let us make it worse. Instead, we have to embrace and invite him to do more. I salute

\begin{abstract}
him, because he still remembers taking medicine and is willing to follow the treatment steps. I also feel responsible even though I'm not a biological sibling, to take care of each other. I usually ask him for a walk to the neighbor's house, ask him to clean up so he can stay active. also paying attention to what he has eaten, sometimes he often forgets."
\end{abstract}

ARD viewed the condition experienced by ODS as a disease that could be treated as long as ODS was diligent in taking medication. For him, ODS was hampered by his disease and he did not want to add to these obstacles. He preferred to involve ODS in his daily activities and remind him to eat.

\subsection{Discussion}

From the cognitive aspect, the extended family living in the same house viewed the mental disorders experienced by ODS as destiny because this was not something that was planned and was not known beforehand. Meanwhile, extended families who lived in a separate house viewed mental disorders experienced by ODS as a disaster that threatened the family name and it was miserable.

Family perceptions of ODS is one of the factors in supporting healing patients. The family must earn it to reduce negative perceptions and discrimination against ODS and provide social support, empathy, acceptance, encourage social interaction, and the urge not to give up and keep trying to ODS.

From the affective aspect, the extended family living in the same house felt a sense of responsibility towards ODS because they regarded ODS as part of the family too. The extended family living in the same house also felt familiar with the ODS' situation because they met every day so that they also felt a sense of understanding towards ODS. Whereas in extended families who lived separately, shame was felt because the mental disorders experienced by ODS also dragged big family's names and heads. Shyness also resulted from symptoms of mental disorders that appeared regardless of time and situation. In addition to shame, feelings of sadness were also felt by the extended family who lived in the same house because they tried to feel pressure and problems in ODS that caused ODS to experience mental disorders. Extended families who did not live 
together often wonder why ODS must experience this mental disorder. Another feeling felt by the extended family who did not live in the same house was fear, which was caused by fear of mental disorder symptoms that appeared in ODS in the form of aggressiveness such as hitting, screaming, throwing things and going berserk.

From the conative aspect, the extended family who lived together admitted that they often approached ODS to avoid stigma from other family members. Approaching ODS was also done before inviting ODS to seek medical help. The extended family who lived in the same house also supported and cared for ODS by taking them seriously and considering them as normal people after giving punishment to ODS' negative behaviour. The behaviour of involving ODS in household chores was shown by inviting ODS to sweep the yard and provide financial assistance. It was demonstrated by giving cigarette money after ODS helped sweep the yard. ODS' extended family also helped ODS daily by providing coffee and bringing food when ODS asked. Meanwhile, the behaviour of staying away from ODS in extended families who did not live together was done by not greeting ODS and pretending not to see ODS. This behaviour was based on fear that ODS suddenly went frantic and felt embarrassed when they were seen interacting with ODS.

Family's negative behaviour towards ODS shows that the family doesn't know clearly about schizophrenia symptoms. When a family knows the symptoms, the family will be able to take control of negative or positive symptoms that appear in ODS.

\subsection{Conclusion}

Based on the findings above, it can be concluded that there were differences in the extended family's attitude towards ODS living in the same house and living in the different house. Positive attitude towards ODS was owned by the extended family who lived in the same house, while a negative attitude was owned by the extended family who lived in the separate house.

Different attitudes shown by extended families towards ODS were caused by differences in information sources, where the extended family living in the same house with ODS witnessed the condition of ODS, while those who lived in the different house with ODS received information about ODS through hearing from other people.

The information or knowledge about schizophrenia helps families to eliminate those unfavourable stigmas to schizophrenia patients, so the family will not have wrong beliefs in schizophrenia. Besides, patients need comprehensive and sustainable attention from the family in a very long period of time in order to maintain their mental stability.

\section{AUTHORS' CONTRIBUTIONS}

N. L. K. N. Rastafary: Conceived and designed the research, collected and analyzed data, wrote the manuscript.

M. Sampe Tondok: Provided critical feedback and helped shape the research, analysis and manuscript.

\section{ACKNOWLEDGMENTS}

I would like to express my deep gratitude to David Hizkia Tobing, S.Psi., M.A and Yohanes Kartika Herdiyanto, S.Psi., M.A, my research supervisors, for their patient guidance, assistance in keeping my progress on schedule and enthusiastic encouragement for this research. I would also like to thank all of the participants of this research for their contribution and valuable support.

\section{REFERENCES}

[1] World Health Organization. The World Health Report 2013: Research for universal health coverage. World Health Organization (contributor). 2013.

[2] Kementrian Kesehatan Republik Indonesia. Hasil utama RISKESDAS 2018. 2018. Available from https://kesmas.kemkes.go.id/assets/upload/dir _519d41d8cd98f00/files/Hasil-riskesdas2018_1274.pdf

[3] P. Lestari. Kecenderungan atau sikap keluarga penderita gangguan jiwa terhadap tindakan pasung (Studi kasus di RSJ Amino Gondho Hutomo Semarang). JKJ, 2(1) (2014) 14-23.

[4] F.S. Lestari, Kartinah. (2012). Hubungan persepsi keluarga tentang gangguan jiwa dengan sikap keluarga kepada anggota keluarga yang mengalami gangguan jiwa di 
rumah sakit jiwa daerah Surakarta. Publikasi ilmiah. 2012. Available from https://publikasiilmiah.ums.ac.id/bitstream/ha ndle/11617/3675/FITRI\%20SRI\%20LESTAR I\%20\%20KARTINAH\%20Fix\%20bgt.pdf?se quence $=1$

[5] D.G. Myers. Social psychology (11 $1^{\text {th }}$ edition). New York: McGraw-Hill; 2014.

[6] A. Wawan, M. Dewi. Teori dan pengukuran pengetahuan sikap dan perilaku manusia. Yogyakarta: Nuha Medika; 2011.

[7] S. Notoatmodjo. Pengantar pendidikan kesehatan dan ilmu perilaku kesehatan. Yogyakarta: Andi Offset; 2010

[8] Sudiharto. Asuhan keperawatan keluarga dengan pendekatan keperawatan transkultural. Jakarta: EGC; 2007

[9] A. Bailon, G.A.S.Maglaya, Family health nursing. Quezon City Philippines: UP College of Nursing; 1989

[10] N.K. Denzin, Y.S. Lincoln, Y. S. Handbook of qualitative research. Fifth edition. Los Angeles: SAGE; 2018

[11] J.W. Cresswell. Research design: Qualitative, quantitative and mixed method approaches. Fourth edition. Thousand Oaks, CA: Sage; 2014.

[12] C. Moustakas. Phenomenological research methods. Thousand Oaks, CA: Sage; 1994.

[13] L.J. Moleong. Metodologi penelitian kualitatif. Bandung: PT. Remaja Rosdakarya; 2014. 